\title{
PEMODELAN BUSINESS PROCESS IMPROVEMENT APLIKASI ANTRIAN PENGAMBILAN STNK (STUDI KASUS : KANTOR KEJAKSAAN KARAWANG)
}

\author{
Lila Setiyani $^{1}$, Reni Rachmawati ${ }^{2}$ \\ ${ }^{1,2}$ Program Studi Sistem Informasi STMIK ROSMA \\ lila.setiyani@dosen.rosma.ac.id ${ }^{1}$,reni.rachmawati@mhs.rosma.ac.id ${ }^{2}$
}

\begin{abstract}
Abstrak
Penumpukan antrian pada pengambilan STNK di Kantor Kejaksaan Karawang menyebabkan kekecewaan masyarakat, sehingga berdampak pada nilai kualitas pelayanan. Permasalahan ini muncul karena pengelolaan antrian yang tidak efektif dan efisien. Penelitian ini bertujuan untuk menyusun pemodelan penyederhanaan dari proses bisnis antrian tersebut, yang dapat diimplementasikan oleh Kantor Kejaksaan. Penelitian ini menggunakan pendekatan business process improvement. Analisis proses bisnis dilakukan melalui wawancara secara mendalam dari dua responden yaitu staf kejaksaan dan masyarakat. Hasil analisis kemudian di intepretasikan menggunakan busniness process modelling notation(BPMN) yang kemudian disederhanakan sehingga didapat model proses bisnis yang lebih efektif dan efisien. Hasil penelitian ini berupa model aplikasi antrian pengambilan STNK yang dapat di implementasikan pada Kantor Kejaksaan Karawang. Penelitian ini berkontribusi dalam peningkatan kualitas dan kepuasan masyarakat terhadap layanan dari Kantor Kejaksaan Karawang.
\end{abstract}

Kata Kunci: STNK, Business Process Improvement, BPMN

\begin{abstract}
The stacking of queues on the collection of Vehicle Registration Certificates (STNK) at the Karawang Prosecutor's Office caused public disappointment, thus affecting the value of service quality. This problem arises because the management of queues is not effective and efficient. This research aims to develop a simplified modeling of the queuing business process, which can be implemented by the Prosecutor's Office. This research uses a business process improvement approach. The business process analysis was carried out through in-depth interviews from two respondents namely the attorney's staff and the community. The results of the analysis are then interpreted using the business process modeling notation (BPMN) which is then simplified to obtain a more effective and efficient business process model. The results of this study are in the form of a vehicle registration queue application model that can be implemented at the Karawang Prosecutor's Office. This research contributes to improving the quality and satisfaction of the community towards the services of the Karawang Prosecutor's Office.
\end{abstract}

Keywords: STNK, Business Process Improvement, BPMN

\section{Pendahuluan}

Kantor Kejaksaan Karawang sebagai salah satu instansi pemerintah yang mengelola proses terkait peradilan dalam perkara Tilang. Dalam proses peradilan perkara Tilang tersebut, terdapat proses pengambilan STNK oleh para pelanggar lalu 
lintas yang telah di adili. Dalam proses tersebut, ternyata masyarakat banyak mengalami kendala dalam pengambilan STNK setelah proses peradilan. Kendala tersebut sangat terlihat ketika proses antrian pengambilan STNK. Melihat tersebut, manarik peneliti untuk menganalisis lebih dalam terkait proses pengambilan STNK pada Kantor Kejaksaan Karawang, yang selanjutnya ditindak lanjuti dengan melakukan penyederhanaan proses, sehingga didapat proses pengelolaan antrian yang lebih efektif dan efisien.

Beberapa peneliti terdahulu mengungkapkan, bahwa untuk dapat menyederhanakan suatu proses bisnis, dapat dilakukan dengan menggunakan pendekatan Business Process Improvement(BPI). Waluyo et. al dalam penelitiannya telah melakukan penyederhanaan proses bisnis pada Toko Buku Galuh menggunakan BPI framework (Waluyo, Aknuranda, \& Setiawan, 2018). Sedangkan Larasati et. al juga berargumen bahwa BPI dapat digunakan dalam perbaikan proses bisnis pemasaran dan pelayanan pelanggan PT. Petrokimia Gresik(Larasati, Wicaksono, \& Wardani, 2017). Begitupun Dwiartono et. al dalam penelitiannya BPI dapat digunakan untuk menyusun rekomendasi perbaikan proses bisnis pada PT. Trivia Nusantara. Helmi et.al juga memperkuat bahwa BPI dapat diguankan untuk membatu menganalisis dan menyusun pemodelan proses bisnis pada Lembaga Bimbingan Belajar Prisma(Helmi, Aknuranda, \& Saputra, 2018). Putri et.al dalam penelitiannya, menggunakan BPI untuk menyusun rekomendasi perbaikan proses bisnis pada Badan Penjaminan Mutu Universitas Widyagama Malang(Putri, Setiawan, \& Aknuranda, 2018). Achmad et.al juga menggunakan BPI dalam meningkatkan proses bisnis penjualan, produksi dan pembelian CV. Cahaya Abadi Teknik(Achmad, Rispianda, \& Liansari, 2016). Hende et.al menggunakan BPI untuk merancang perbaikan proses bisnis pada layanan penerbitan majalah(Hende, Setiawan, \& Mursityo, 2018). Putra et.al juga menggunakan BPI untuk melakukan analisis dan evaluasi terhadap proses bisnis pada UB Guest House. Nurfitria dan Dewantara juga telah membuktikan bahwa BPI merupakan pendekatan yang dapat digunakan untuk menganalisis proses bisnis sistem informasi administrasi skripsi pada program studi ilmu administrasi bisnis fakultas ilmu administrasi Universitas Brawijaya(Nurfitria, 2018). Susanto et.al menggunakan BPI untuk melakukan anlisis dan perbaikan proses bisnis pada PT. Wonojati Wijoyo(Indra Fahrizal, Ismiarta Aknuranda, 2018). Yuthika et.al juga mengungkap bahwa BPI dapat digunakan untuk merancang Standar Operasional Prosedur(SOP) pengendalian informasi terdokumentasi berdasarkan ISO 9001:2015 klausul 7.5 dan ISO 14001:2015 klausul 7.5(Yuthika et al., 2016).

Melihat beberapa penelitian terdahulu tersebut, maka dalam penelitian ini, peneliti menggunakan pendekatan BPI sebagai teori yang mendasari proses penyederhanaan bisnis proses pada proses pengelolaan antrian pengambilan STNK Kantor Kejaksaan Karawang, dengan harapan model penyederhanaan ini dapat diimplementasi dan berkontribusi memberikan pelayanan yang memuaskan bagi masyarakat sebagai pengguna layanan Kantor Kejaksaan Karawang.

\section{Landasan Penelitian}

Business Process Improvement(BPI) merupakan pendekatan sistematik yang membentu organisasi untuk mengoptimalkan proses dasar untuk mencapai hasil yang lebih efisien(Von Rosing, Von Scheel, \& Scheer, 2014). BPI bertujuaan untuk mengeliminasi kesalahan - kesalahan, memberikan perusahaan keuntungan yang competitive dengan peningkatan proses bisnis, memenuhi permintaan pelanggan dan tujuan bisnis yang lebih efektif(Fabbly, 2019). Dalam BPI terdapat lima fase seperti yang terlihat pada gambar berikut :

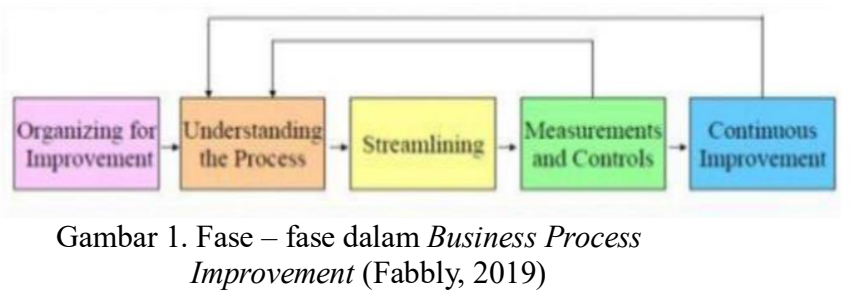


Berikut penjelasan terkait fase - fase dalan BPI :

- Organizing for improvement : pengorganisasian perbaikan yang bertujuan untuk mengelola proses bisnis organisasi secara internal maupun eksternal agar menjadi lebih baik. Proses pendefinisian tersebut meliputu pemilihan proses, pendefinisian batas - batas awal perbaikan, pembentukan dan pelatihan tim perbaikan proses, pengembangan model perbaikan, penetapan ukuran - ukuran keberhasilan.

- Understanding the process : pemahaman proses yang dilakukan untuk mencapai pemahaman seluruh dimensi yang ada di dalam proses bisnis yang berlangsung dalam oragnisasi sehingga proses yang berjalan menjadi jelas dan dimengerti oleh masing - masing dimensi fungsional dari bagan arus proses maupun prosedur yang ada didalamnya. Dalam tahap ini hal hal yang dilakukan diantaranya adalah membuat bagan alir proses, melihat hubungan - hubungan yang ada pada proses yang berjalan, melakukan analisa waktu proses, pelaksanaan perbaikan cepat, pengaturan proses dan prosedur.

- Streamlining : proses yang dilakukan untuk penyederhanan proses dengan mengurangi waktu, menstandarisasi maupun memperbaharui proses yang semuanya bertujuan untuk memperbaiki efisiensi, efektivitas dan adaptabilitas dari proses bisnis yang berjalan. Hal - hal yang dilakukan pada tahap ini adalah menyederhanakan proses, pemilihan proses yang dikehendaki, mengurangi birokrasi, meng-upgrade peralatan, standarisasi proses, mengurangi waktu proses.

- Measurements and Controls: pengukuran dan pengontrolan proses bisnis dilakukan untuk mengontrol jalannya proses bisnis dengan melakukan pemeriksaan dan pengukuran terhadap prediksi target yang dicapai organisasi. Hal - hal yang dilakukan pada tahap ini adalah mengembangkan pengukuran proses dan target yang dicapai, menyediakan system umpan balik, melakukan pemeriksaan proses secara berkala.

- Continnuos Improvement : perbaikan berkelanjutan dilakukan dengan tujuan untuk mencapai pengeimplementasian proses perbaikan selanjutnya dengan berbagai proses seprti perubahan, menghapus, menambahkan proses dan sebagainya. Hal - hal yang perlu dilakukan pada tahap ini adalah mengevaluasi dampak perubahan terhadap bisnis dan pelanggan, mengkualifikasikan proses, mencari dan menghilangkan masalah proses, studi banding proses, melihat kembali kualifikai secara berkala.

Dalam pemodelan proses bisnis, peneliti menggunakan Business Process Modelling Notation (BPMN) yang merupakan strandar untuk memodelkan proses bisnis dan proses proses web servis. Dalam BPMN tersedia notasi yang dapat dengan mudah dipahami oleh semua pengguna bisnis termasuk analis bisnis yang menciptakan draf awal dari proses sampai pengembangan teknis yang bertanggung jawab untuk mengimplementasikan teknologi yang digunakan dalam menjalankan proses proses tersebut(Krisantoso, Ap, Fajar, \& Kharisma Makassar, 2015).

\section{Metode Penelitian}

Penelitian ini memiliki paradigma Design Science yang berakar pada domain teknisk sains artifisial. Pradigma ini merupakan paradigma pemecahan masalah yang berfokus pada pencarian inovasi dalam meningkatan efisiensi dan efektivitas dari pengelolaan antrian pengambilan STNK. Penelitian ini merupakan penelitian kualitatif dengan menggunakan metode wawancara 
sebagai teknik pengumpulan data. Narasumber dari penelitian ini adalah staf antrian pada Kantor Kejaksaan Karawang dan Masyarakat yang terlibat dalam proses antrian pengambilan STNK. Berdasarkan data hasil wawancara peneliti menggunakan pendekatan BPI untuk menyederhanakan proses antrian pengambilan STNK. Penelitian ini dilakukan sampai tersusun proses bisnis yang lebih sederhana dari proses yang sebelumnya. Sehingga prosedur penelitian ini dapat digambarkan sebagai berikut :

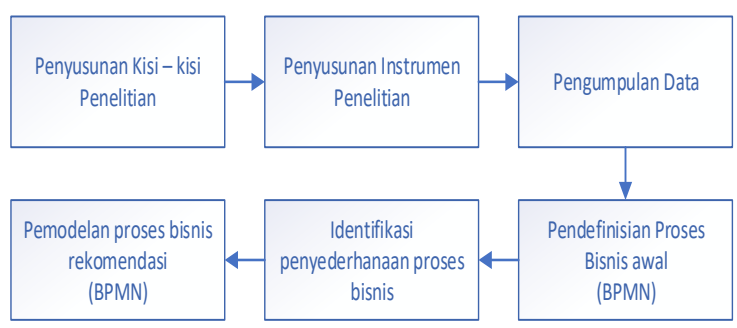

Gambar 2. Prosedur penelitian

\section{Hasil dan Pembahasan}

Berikut adalah hasil dari penelitian yang berdasar pada setiap tahapan :

Penyusunan Kisi - kisi , instrumen dan pengumpulan data penelitian.

TABEL 1. KISI - KISI PENELITIAN

\begin{tabular}{|c|c|c|}
\hline $\begin{array}{l}\text { Data/Informasi } \\
\text { yang digali }\end{array}$ & Sumber Data & $\begin{array}{c}\text { Teknik } \\
\text { Pengumpulan } \\
\text { Data }\end{array}$ \\
\hline $\begin{array}{l}\text { Proses bisnis } \\
\text { dalam } \\
\text { pengambilan } \\
\text { STNK pada } \\
\text { Kantor Kejaksaan } \\
\text { Karawang }\end{array}$ & $\begin{array}{l}\text { Staf } \\
\text { pengambilan } \\
\text { STNK dan } \\
\text { Masyarakat } \\
\text { pengguna } \\
\text { layanan pada } \\
\text { Kantor } \\
\text { Kejaksaan } \\
\text { Karawang }\end{array}$ & Wawancara \\
\hline $\begin{array}{l}\text { Pelaku yang } \\
\text { terlibat dalam } \\
\text { proses } \\
\text { pengambilan } \\
\text { STNK pada } \\
\text { Kantor Kejaksaan } \\
\text { Karawang }\end{array}$ & $\begin{array}{l}\text { Staf } \\
\text { pengambilan } \\
\text { STNK dan } \\
\text { Masyarakat } \\
\text { pengguna } \\
\text { layanan pada } \\
\text { Kantor } \\
\text { Kejaksaan } \\
\text { Karawang }\end{array}$ & Wawancara \\
\hline $\begin{array}{l}\text { Kendala } \\
\text { kendala yang } \\
\text { dihadapi dalam } \\
\text { pengambilan } \\
\text { STNK pada } \\
\text { Kantor Kejaksaan }\end{array}$ & $\begin{array}{l}\text { Staf } \\
\text { pengambilan } \\
\text { STNK dan } \\
\text { Masyarakat } \\
\text { pengguna } \\
\text { layanan pada }\end{array}$ & Wawancara \\
\hline
\end{tabular}

\begin{tabular}{llc}
\hline $\begin{array}{c}\text { Data/Informasi } \\
\text { yang digali }\end{array}$ & Sumber Data & $\begin{array}{c}\text { Teknik } \\
\text { Pengumpulan } \\
\text { Data }\end{array}$ \\
\hline Karawang & Kantor & \\
& Kejaksaan & \\
& Karawang & \\
\hline
\end{tabular}

Berdasarkan hasil pengumpulan data dari narasumber yang telah diwawancarai, dapat didefinikan proses bisnis awal dari pengambilan STNK pada Kantor Kejaksaan Karawang adalah sebagai berikut :

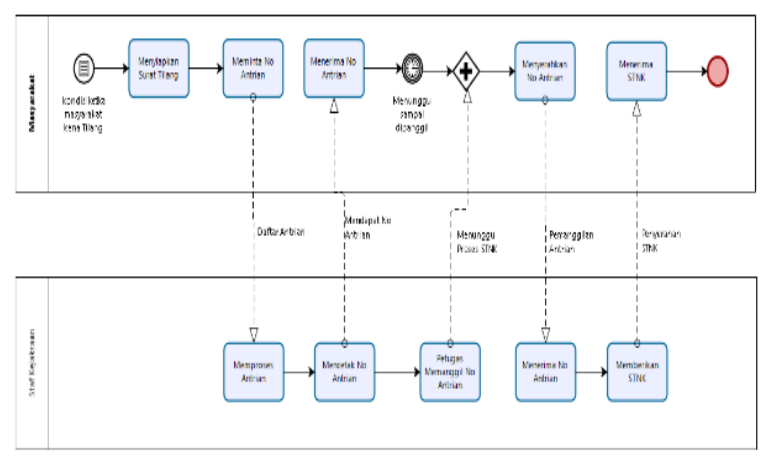

Gambar 3. Proses bisnis awal antrian pengambilan STNK pada Kantor Kejaksaan Karawang

Proses bisnis ini diawali dengan kondisi tertentu yaitu masyarakat pengguna lalu lintas jalan raya yang terkena Tilang karena pelanggaran. Untuk mengambil STNK pada kantor Kejaksaan Karawang masyarakat yang berkepentingan mempersipakan surat tilang kemudian mengambil nomor antrian. Setelah masyarakat mendapatkan nomor antrian, kemudian masyaratkan menunggu dipanggil petugas berdasarkan nomor antrian yang telah diambil. Ketika petugas memanggil nomor antrian, kemudian masyarakat menyerahkan nomor antrian dan petugas menyerahkan STNK.

Berdasarkan analisis proses bisnis yang telah digambarakan pada gambar 3, dapat diidentifikasi beberapa penyederhanaan sebagai berikut :

a. Pendaftaran pengambilan STNK dapat dilakukan melakukan aplikasi sehingga masyarakat hadir ketika STNK sudah siap.

b. Pendafatran pengambilan STNK melalui aplikasi dapat menghemat biaya kertas 
c. Pendaftaran pengambilan STNK melalui aplikasi dapat mengilangkan proses tunggu pemangilan antrian.

d. Pendaftaran pengambilan STNK melalui aplikasi membuat masyarakat tidak perlu hadir ke kantor Kejaksaan ketika mendaftar.

Berdasarkan hasil identifikasi penyederhanaan proses bisnis maka dapat dilakukan pemodelan BPI yang direkomendasikan sebagai berikut :

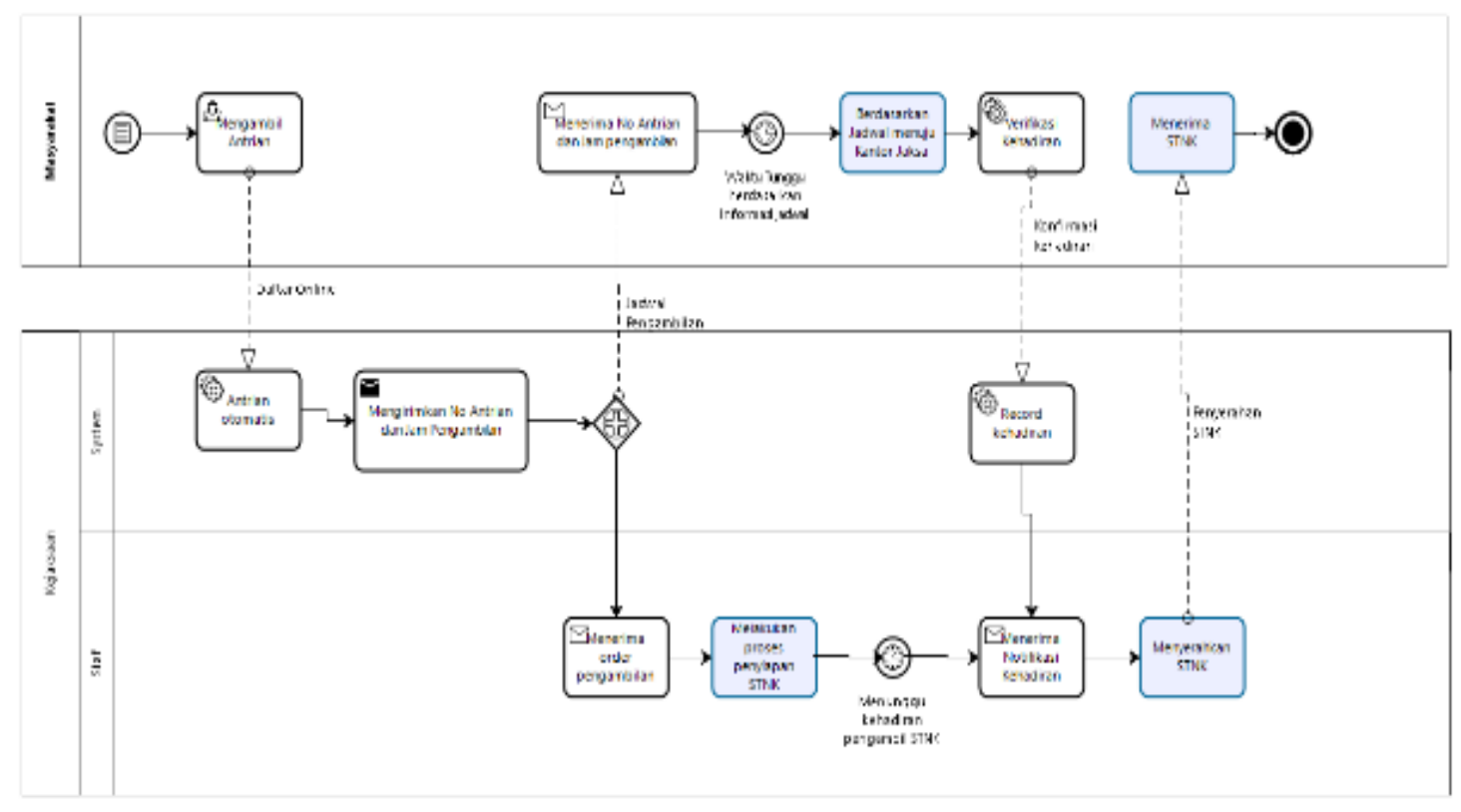

Gambar 4. Penyederhanaan proses bisnis

Berdasarkan penyederhanaan proses bisnis ada beberapa pengelolaan di akomodir oleh aplikasi seperti proses pengambilan antrian dan penginformasian jadwal serta verifikasi kehadiran, yang akan mengambil STNK. Sedangkan proses yang masih dilakukan manual adalah penyiapan dan penyerahan STNK oleh staf atau petugas kejaksaan.

Perbaikan proses bisnis dari pengambilan STNK di Kantor Kejaksaan Karawang dapat diimpelementasi dengan beberapa ketentuan sebagai berikut :

a. Infrastruktur

Untuk dapat mengimplementasikan,

Kantor Kejaksaan Karawang perlu menyiapkan infrastrukur yang dapat menunjang aplikasi pendaftaran pengambilan STNK. Infrastruktur tersebut dapat berupa server, jaringan internet dan lain - lain.

b. Fitur aplikasi

Pendaftaran pengambilan STNK dapat difasilitasi melalui mobile aplication yang memiliki beberapa fitur sebagai beriku :

1) Masyarakat

Fitur - fitur yang ada di menu masyarakat diantaranya pembuatan account, pendaftaran pengambilan STNK, jadwal dan pengambilan, pengaduan keluahan, dan penilaian layanan.

2) Admin kejaksaan

Fitur yang ada di menu admin kejaksaan diantaranya pengelolaan pendaftaran pengambilan STNK, penjadwalan pengambilan STNK, verifikasi pengambilan STNK, pengelolaan pengaduan, dan laporan - laporan.

Selain itu aplikasi yang akan digunakan perlu memenuji kualitas jaminan sistem yaitu :

1) Correctness (kebenaran), tingkat pemenuhan program terhadap kebutuhan yang dispesifikasikan 
dan memenuhi tujuan/misi pengguna.

2) Reliability (Keandalan), tingkat kemampuan program yang diharapkan dapat menampilkan fungsi yang dimaksud dengan presisi yang ditetapkan.

3) Efficiency (efisiensi), jumlah sumberdaya yang diproses dan kode yang diperlukan oleh program untuk melaksanakan fungsinya.

4) Integrity (Integritas), tingkat kemampuan pengawasan akses terhadap data atau software oleh orang-orang tertentu.

5) Usability, usaha yang diperlukan untuk mempelajari, mengoperasikan, menyiapkan masukan dan mengartikan keluaran program.

6) Maintainability, usaha yang diperlukan untuk menetapkan dan memperbaiki kesalahan dalam program.

7) Flexibility, usaha yang diperlukan untuk memodifikasi program operasional.

8) Testability, usaha yang diperlukan untuk menguji program untuk memastikan bahwa program melaksanakan fungsi yang telah ditetapkan.

9) Portability, usaha yang diperlukan untuk memindahkan program dari hardware/lingkungan sistem software tertentu ke yang lainnya.

10) Reusability, tingkat kemampuan program/bagian dari program yang dapat dipakai ulang dalam aplikasi lainnya, berkaitan dengan paket dan lingkup dari fungsi yang dilakukan oleh program.

11) Interoperability, usaha yang diperlukan untuk menggabungkan satu sistem dengan sistem lainnya.

c. Sosialisasi kepada masyarakat

Dalam rangka implementasi sebuah sistem, masyarakat sebagai objek pengguna perlu di berikan informasi tetang alur proses yang baru serta panduan penggunaan aplikasi tersebut, sehingga masyarakat dapat dengan mudah belajar dan beradaptasi terhadap proses bisnis baru.

d. Layanan pengaduan

Kantor kejaksaan sebagai instansi pemerintah dirasa perlu mengutamakan layanan yang berkualitas kepada masyarakat maka, untuk dapat meningkatkan layanan dan menunjang perbaikan yang terus menerus memerlukan layanan pengaduan yang diperuntukan kepada masyarakat yang mengalami gangguan atau kendala terkait pengambilan STNK ini.

\section{Kesimpulan dan Rekomendasi}

Dalam penelitian ini, BPI telah menjadi suatu kerangka yang memandu dalam penyederhadaan suatu proses bisnis. Penyederhanaan proses bisnis pada pengambilan STNK pada Kejaksaan Karawang berdampak pada pengelolaan pendaftaran yang dikelola oleh aplikasi, karena efektivitas dan efisiensi dapat dilakukan melalui fitur - fitur yang dapat disediakan oleh aplikasi. Pengelolaan secara aplikasi dapat menghilangkan masa tunggu masyarakat, sehingga masyarakat dapat hadir sesuai jadwal, disamping itu, penggunaan aplikasi memberikan kemudahan dalam pengambilan keputudan serta pengontrolan dalam proses bisnis pengambilan STNK pada Kejasaan Karawang. Dalam proses implementasi Kejaksaan Karawang perlu memperhatikan beberapa hal diantaranya infrastrukktur, fitur aplikasi, teknik sosialisasi dan layanan pengaduan. Infrastruktur menjadi faktor yang sangat penting, karena aplikasi tidak dijalankan jika tidak infrastruktur yang berkualitas. Fitur aplikasi menjadi sebuah hal yang perlu digali lebih dalam untuk mengetahui kebutuhan dari dua aktor pengguna yaitu masyarakat dan petugas atau staf Kejaksaan. Sedangkan teknik sosialisasi dan layanan pengaduan mendukung dari proses implementasi proses bisnis yang baru. Penyederhanaan proses bisnis ini dapat berkontribusi pada peningkatan nilai pelayanan Kantor Kejaksaan kepada 
masyarakat. Semakin cepat, mudah dan mengakomodir kendala yang timbul di masyarakat, maka akan semakin tinggi tingkat kepuasan masyarakat terhadap layanan pengambilan STNK pada Kejaksaan Karawang.

\section{Daftar Pustaka}

Achmad, F. I., Rispianda, \& Liansari, G. P. (2016). Business Process Improvement Untuk Proses Penjualan, Produksi Dan Pembelian di CV. Cahaya Abadi Teknik. Jurnal Online Institut Teknologi Nasional, 4(01), 382-393.

Fabbly. (2019). Business Process Improvement.

https://doi.org/10.1201/b12270-7

Helmi, A. T., Aknuranda, I., \& Saputra, M. C. (2018). Analisis Dan Pemodelan Proses Bisnis Menggunakan Business Process Improvement (BPI) Pada Lembaga Bimbingan Belajar (Studi Kasus: Lembaga Bimbingan Belajar Prisma). Jurnal Pengembangan Teknologi Informasi Dan Ilmu Komputer (JPTIIK) Universitas Brawijaya, 2(10).

Hende, R. Y. L., Setiawan, N. Y., \& Mursityo, Y. T. (2018). Perancangan Perbaikan Bisnis Proses Menggunakan Metode Business Process Improvement Pada Layanan Penerbitan Majalah. Jurnal Pengembangan Teknologi Informasi Dan Ilmu Komputer, 2(3), 1328-1336.

Indra Fahrizal, Ismiarta Aknuranda, N. Y. S. (2018). Analisis Dan Perbaikan Proses Bisnis Menggunakan Metode Business Process Improvement ( BPI ) ( Studi Kasus : PT . Wonojati Wijoyo ). Jurnal Pengembangan Teknologi Informasi Dan Ilmu Komputer, 2(12), 6201-6209.

Krisantoso, G., Ap, I., Fajar, M., \& Kharisma Makassar, S. (2015). Penerapan Business Process Modeling Notation (Bpmn) Untuk Memodelkan Kebutuhan Sistem Proses Penyuntingan Tulisan Pada Website Jurnal Jtriste. Seminar Nasional Forum Dosen Indonesia, (August 2015), 2460-5271.

Larasati, S. D., Wicaksono, S. A., \& Wardani, N. H. (2017). Perbaikan Proses Bisnis Menggunakan Metode Business Process
Improvement ( BPI ) ( Studi Pada Bagian Riset Pemasaran dan Pusat. Jurnal Pengembangan Teknologi Informasi Dan Ilmu Komputer (JPTIIK) Universitas Brawijaya, 1(11), 1425-1432.

Nurfitria, R. A. (2018). ANALISIS PROSES BISNIS SISTEM INFORMASI ADMINISTRASI SKRIPSI DENGAN PENDEKATAN BUSINESS PROCESS IMPROVEMENT (Studi Kasus pada Program Studi Ilmu Administrasi Bisnis Fakultas Ilmu Administrasi Universitas Brawijaya). Jurnal Administrasi Bisnis, 64(1), 84-91.

Putri, D. A., Setiawan, N. Y., \& Aknuranda, I. (2018). Rekomendasi Perbaikan Proses Bisnis Dengan Menggunakan Metode Business Process Improvement (BPI) (Studi Kasus: Badan Penjaminan Mutu, Universitas Widyagama Malang). Jurnal Pengembangan Teknologi Informasi Dan Ilmu Komputer, 2(11), 5960-5968. Retrieved from http://jptiik.ub.ac.id

Von Rosing, M., Von Scheel, H., \& Scheer, A. W. (2014). The Complete Business Process Handbook: Body of Knowledge from Process Modeling to BPM. In The Complete Business Process Handbook: Body of Knowledge from Process Modeling to BPM (Vol. 1). https://doi.org/10.1016/C2013-0-135969

Waluyo, A. G., Aknuranda, I., \& Setiawan, N. Y. (2018). Analisis Proses Bisnis Pada Toko Buku Galuh Menggunakan Business Process Improvement Framework. Jurnal Pengembangan Teknologi Informasi Dan Ilmu Komputer (J-PTIIK) Universitas Brawijaya, 2(12), 7568-7574.

Yuthika, R., Widaningrum, S., Lalu, H., Studi, P., Industri, T., Industri, F. R., ... Terdokumentasi, P. I. (2016). Perancangan Sop Pengendalian Informasi Terdokumentasi Klausul 7.5 Dengan Mempertimbangkan Risiko Menggunakan. E-Proceeding of Engineering, 3(2), 2815-2821 